\title{
PENGEMBANGAN UMKM BONTOT SALMINAH SEBAGAI KULINER KHAS KOTA SERANG MENUJU ERA INDUSTRI 5.0
}

\author{
${ }^{1)}$ Hadi Kurniawanto, ${ }^{2}$ Hafidz Hanafiah, ${ }^{3)}$ Ardi Hidayat \\ 1)Fakultas Ekonomi dan Bisnis, Universitas Bina Bangsa \\ ${ }^{1)}$ Email : hadi.kurniawanto@ binabangsa.ac.id \\ ${ }^{2)}$ Fakultas Ekonomi dan Bisnis, Universitas Bina Bangsa \\ ${ }^{2}$ Email : hafidz.hanafiah@binabangsa.ac.id \\ ${ }^{3)}$ Fakultas Ekonomi dan Bisnis, Universitas Bina Bangsa \\ ${ }^{3)}$ Email : ardi.hidayat@binabangsa.ac.id
}

\begin{abstract}
ABSTRAK
Bontot Salminah yang merupakan salah satu kuliner khas Kota Serang. Seiring perkembangan jaman serta menghadapi era industri 5.0, Bontot Salminah masih saja memasarkan produknya secara offline. Metode Penelitian menggunakan deskriptif kualitatif dengan melakukan pendekatan rasionalistik. Pengumpulan data didapat dari eksplorasi informasi dari berbagai sumber. startegi yang optimal untuk Bontot Salminah dalam menyongsong era industri 5.0, yaitu dengan menggunakan Sosial Media Marketing dan Toko Online. Kedua opsi tersebut dirasakan cukup melihat kondisi sekarang mengingat internal Bontot Salminah baik dari segi teknologi, SDM, serta modal menyesuaikan keuangan dari pengelola Bontot Salminah. pengembangan produk Bontot Salminah melakukan label dan kemasan yang menarik (baik dari nama, gambar, ukuran bontot dan desain kemasan) dengan baik. Pemasaran online oleh Bontot Salminah dilakukan melalui Jejaring Sosoal baik Facebook dan Instagram serta masuk ke market place toko online. Karena diyakini sangat efektif mendorong pemasaran. Serta dibuatkan testimoni baik gambar maupun video yang di upload via Youtube.
\end{abstract}

\section{Kata Kunci : Bontot Salminah, Industri 5.0}




\section{PENDAHULUAN}

Seiring dengan meningkatnya UMKM khususnya kuliner di Kota Serang. Hal ini mengindikasikan bahwa meningkatnya kepedulian masyarakat Kota Serang untuk melakukan inovasi kuliner. Salah satunya usaha Bontot Salminah yang merupakan salah satu kuliner khas Kota Serang. Seiring perkembangan jaman serta menghadapi era industri 5.0, Bontot Salminah masih saja memasarkan produknya secara offline. Salah satu permasalahan tersebut dikhawatirkan akan menggerus kuliner khas Kota Serang tersebut oleh kuliner yang kekinian. Berbagai cara dilakukan oleh Pemerintah Daerah setempat dalam mempertahankan kuliner khas tersebut. Mulai dari festival jajanan kuliner khas Kota Serang hingga dibangun komunitas kuliner. Tapi ketika melihat perkembangan kuliner saat ini, hal tersebut dirasakan belum cukup. Peralihan memasarkan produk sudah berkembang ke arah online atau digital.

Berdasarkan data yang dilansir oleh situs http://www.wearesocial.com, sebuah agensi digital marketing di Amerika, menyebutkan bahwa di Indonesia per Januari 2020 disebutkan bahwa ada 175,4 juta pengguna internet di Indonesia. Dibandingkan tahun sebelumnya, ada kenaikan $17 \%$ atau 25 juta pengguna internet di negeri ini. Berdasarkan total populasi Indonesia yang berjumlah 272,1 juta jiwa, maka itu artinya $64 \%$ setengah penduduk RI telah merasakan akses ke dunia maya. Adapun medsos yang paling banyak 'ditongkrongi' oleh pengguna internet Indonesia dari paling teratas adalah YouTube, WhatsApp, Facebook, Instagram, Twitter, Line, FB Messenger, LinkedIn, Pinterest, We Chat, Snapchat, Skype, Tik Tok, Tumblr, Reddit, Sina Weibo.

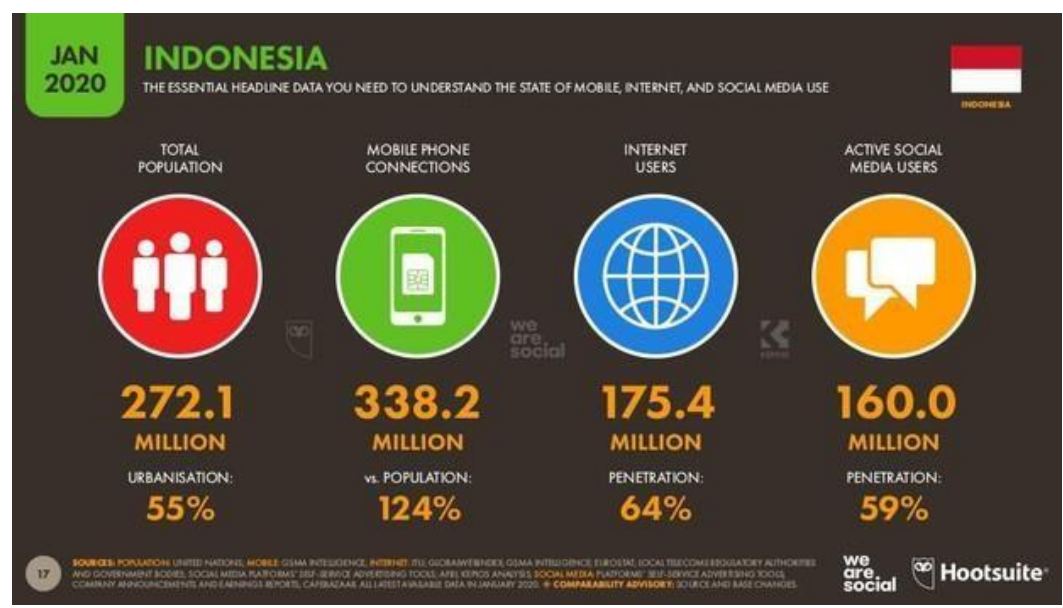

Gambar 1. Data Pengguna Internet di Indonesia pada Januari 2020

Sumber: www.wearesocial.com 


\section{Identifikasi Dan Perumusan Masalah}

1. Pengembangan label dan kemasan produk UMKM yang masih awam dan tradisional dalam menghadapi era industri 5.0.

2. Pengembangan pemasaran secara online serta belum adanya inovasi kuliner bontot sehingga terdapat varian produk yang bisa dinikmati dan dipilih oleh semua kalangan.

3. Pemilihan pemasaran online yang tepat dan disesuaikan dengan kemampuan para pelaku UMKM

\section{Tujuan Penelitian}

Tujuan dari penelitian ini yaitu

1. Untuk menganalisis pengembangan pemasaran produk baik peran label, merek, dan kemasan serta strateginya bagi Bontot Salminah.

2. Untuk mengetahui pemilihan pemasaran online yang tepat untuk Bontot Salminah.

\section{Sejarah Bontot}

Bontot yang merupakan istilah bahasa Serang-Banten yang memiliki arti bungsu atau anak paling terakhir. Inilah yang diyakini asal muasal penamaan bontot, karena si bontot adalah makanan yang bentuknya mungil. Bontot adalah makanan gurih dapat dinikmati siapa saja, terlebih bagi mereka yang sangat suka dengan olahan ikan dan masakan yang bergizi tinggi. Indonesia memiliki kekayaan alam yang luar biasa dan tentu ikan-ikan yang menari di perairan laut, payau bahkan sungai menjadi anugrah tersendiri untuk masyarakatnya.

Masyarakat di Desa Desa Domas, Kecamatan Pontang, Serang, Banten menjadi salah satu masyarakat yang menikmati anugrah kekayaan ikan laut dan ikan payau. Di Desa Domaslah, lahirlah makanan bontot yang berbahan dasar ikan payus. Banyaknya kalsium yang terkandung dalam tulang ikan payus bisa diolah menjadi tepung untuk pembuatan aneka makanan lainnya yang banyak memilik gizi dan protein yang baik untuk tubuh (http://faizatulmuhlisoh.blogspot.com/2016/12/sejarah-makanan-khas-serang-bontot.html diakses pada tanggal 10 April 2020)

\section{Label Produk Makanan/Pangan}

Menurut Peraturan Pemerintah Republik Indonesia No. 69 Tahun 1999, tentang Label 
dan Iklan Pangan, label pangan adalah setiap keterangan mengenai pangan yang berbentuk gambar, tulisan, kombinasi keduanya, atau bentuk lain yang disertakan pada pangan, dimasukkan ke dalam, ditempelkan pada, atau merupakan bagian kemasan pangan.

Menurut Angipora, label merupakan suatu bagian dari produk yang membawa informasi verbal tentang produk atau penjualnya (Angipora, 2002). Berdasarkan pengertian tersebut di atas label merupakan suatu yang sangat penting bagi produk makanan karena dengan label tersebut konsumen dapat mengenal dan mengingat produk tersebut, hal ini disebabkan produk telah memiliki identitas yang berisi informasi tentang produk tersebut.

Menurut Kotler (2000), fungsi label sebagai berikut:

1) Label mengidentifikasi produk/ merek

2) Label menentukan kelas produk

3) Label menggambarkan beberapa hal mengenai produk (pembuatnya, dimana dibuat, kapan dibuat, kandungan isinya, tata cara penggunaannya secara aman)

4) Label mempromosikan produk lewat aneka gambar yang menarik.

Menurut Swastha (1984), terdapat tiga macam label yang sering digunakan oleh beberapa perusahaan, yaitu:

1) Brand label adalah label yang semata-mata sebagai brand. Contoh kain atau tekstil tertulis : "sanforized, berkolin, tetoron", dan sebagainya. Nama tersebut digunakan oleh perusahaan yang memproduksinya. Selain brand label tersebut, perusahaan juga mencantumkan merek yang dimilikinya pada tekstil yang diproduksi.

2) Grade label adalah label yang menunjukkan tingkat kualitas tertentu dari suatu barang. Label ini dinyatakan dengan suatu tulisan atau kata-kata.

3) Descriptive label atau informative label merupakan label yang menggambarkan tentang cara penggunaan, susunan, pemeliharaan, hasil kerja dari suatu barang.

Adapun keuntungan penggunaan label yang efektif sebagai berikut:

1) Meningkatkan pemasaran

2) Mendorong promosi yang lebih besar

3) Perlindungan terhadap konsumen

4) Perlindungan terhadap persaingan yang tidak baik

5) Sejalan dengan tujuan ekonomi.

Sedangkan tujuan pelabelan, yaitu: 
1) Memberi informasi tentang isi produk yang diberi label tanpa harus membuka kemasan

2) Berfungsi sebagai sarana komunikasi produsen kepada konsumen tentang hal-hal yang perlu diketahui oleh konsumen tentang produk tersebut, terutama hal-hal yang kasat mata atau tak diketahui secara fisik.

3) Memberi petunjuk yang tepat pada konsumen hingga diperoleh fungsi produk yang optimum. Sarana periklanan bagi produsen.

4) Memberi "rasa aman" bagi konsumen.

Menurut Peraturan Pemerintah Republik Indonesia No. 69 Tahun 1999, tentang Label dan Iklan Pangan, keterangan yang tercantum pada label sekurang-kurangnya memuat :

1) Nama produk

2) Daftar bahan yang digunakan

3) Berat bersih atau isi bersih

4) Nama dan alamat pihak yang memproduksi / yang masuk ke dalam wilayah Indonesia;

5) Tanggal, bulan, dan tahun kadaluwarsa.

Mengingat label adalah alat penyampai informasi, sudah selayaknya informasi yang termuat pada label adalah sebenar-benarnya dan tidak menyesatkan. Hanya saja, mengingat label juga berfungsi sebagai iklan, di samping sudah menjadi sifat manusia untuk mudah jatuh dalam kekhilafan dengan berbuat curang baik yang disengaja maupun yang tidak disengaja, maka perlu dibuat rambu-rambu yang mengatur. Dengan adanya rambu-rambu ini diharapkan fungsi label dalam memberi rasa aman pada konsumen dapat tercapai.

\section{Pengemasan Produk Makanan}

Menurut Danger, pengemasan adalah desain dan pembuatan kemasan untuk barang eceran, diterapkan sama kepada produk konsumsi untuk produk industrial. Pengemasan merupakan subjek yang kompleks yang telah menjadi satu bagian penting dari promosi produk apa saja, walaupun dikhususkan untuk produk makanan, dan ini tidak dapat dipisahkan dari pemasaran. Hendaknya dapat dibedakan antara pengemasan dan kemasan, walaupun keduanya sering diartikan sama (Danger, 1992). Pengemasan mencakup keseluruhan konsep termasuk kemasan langsung, bagian luar, pembungkus dan lain-lainnya, dan bagian yang keseluruhannya berperan dalam pemasaran dan pemajangan. Sebuah kemasan yang baik tidak akan menjual produk apapun jika konsep pengemasannya tidak tepat, dan juga tidak akan 
menjual produk yang buruk. Sebuah kemasan yang buruk bisa memberikan citra yang jelek bagaimanapun baiknya pemikiran atas konsep pengemasannya. terhadap suatu produk yang sangat baik, Berdasarkan bahan dasar pembuatannya maka jenis kemasan pangan adalah kemasan kertas, gelas, kaleng/logam, plastik dan kemasan komposit atau kemasan yang merupakan gabungan dari beberapa jenis bahan kemasan, contoh gabungan antara kertas dan plastik atau plastik, kertas dan logam. Karakteristik jenis bahan kemasan sebagai berikut: (1) kemasan kertas, (2) kemasan gelas, (3) kemasan logam (kaleng), (4) kemasan plastik, dan (5) komposit (kertas/plastik).

Pemilihan jenis kemasan untuk bahan pangan, harus mempertimbangkan syarat kemasan yang baik untuk produk tersebut serta karakteristik produk yang dikemas. Syarat yang harus dipenuhi oleh suatu kemasan agar dapat berfungsi dengan baik adalah:

1) Harus dapat melindungi produk dari kotoran dan kontaminasi sehingga produk tetap bersih.

2) Harus dapat melindungi dari kerusakan fisik, perubahan kadar air, gas, dan penyinaran (cahaya).

3) Mudah untuk dibuka/ditutup, mudah ditangani serta mudah dalam pengangkutan dan distribusi.

4) Efisien dan ekonomis khususnya selama proses pengisian produk ke dalam kemasan.

5) Harus mempunyai ukuran, bentuk dan bobot yang sesuai dengan norma atau standar yang ada, mudah dibuang dan mudah dibentuk atau dicetak.

6) Dapat menunjukkan identitas, informasi dan penampilan produk yang jelas agar dapat membantu promosi atau pemasaran.

Menurut Nillson \& Ostrom (2005) dalam Cahyorini \& Rusfian (2011), variabel desain kemasan terdiri dari 3 dimensi, yaitu:

a. Desain Grafis adalah dekorasi visual pada permukaan kemasan dan terdiri dari empat sub dimensi, yaitu: nama merek, warna, tipografi, dan gambar.

b. Struktur desain berkaitan dengan fitur-fitur fisik kemasan, dan terdiri dari 3 subdimensi: bentuk, ukuran, dan material.

c. Informasi Produk. Salah satu fungsi kemasan adalah untuk mengkomunikasikan produk melalui informasi yang tertera dalam desain kemasan. Informasi produk dapat membantu konsumen dalam membuat keputusan pembelian dengan lebih hati-hati. (Silayoi \& Speece, 
2005). Dimensi-dimensi dari kemasan memiliki peran masing-masing untuk menghasilkan kemasan yang baik dan menarik, karena semakin menarik kemasan tersebut semakin menarik perhatian para konsumen.

Pemasaran secara digital menurut Chaffey (2002:14) adalah penerapan teknologi digital yang membentuk online channel ke pasar yang memberikan kontribusi terhadap kegiatan pemasaran, yang bertujuan untuk mendapatkan keuntungan dan mempertahankan konsumen, lewat usaha mengenali pentingnya teknologi digital dan mengembangkan pendekatan yang terencanauntuk meningkatkankesadarankonsumen, dan kemudian menyampaikan pesanlewatkegiatan komunikasi dan layanan berbasisonline yang terintegrasi dan terfokus untuk memenuhi kebutuhan pelanggan yang spesifik. Adapun dimensi dari pemasaran digital dari sisi promosi sebagai bagian dari bauran pemasaran (4Ps) menurut Ryan (2009: 31) yaitu :

1. Website adalah penghubung dengan dunia digital secara keseluruhan dan bagian yang paling penting dalam keseluruhan strategi pemasaran digital, dimana kegiatan online akan terarah langsung ke calon konsumen.

2. SEO (search engine optimation), atau proses pengaturan konten dari website agar mudah ditemukan oleh pengguna internet yang sedang mencarikonten yang relevan dengan yang ada di website, dan menyajikan konten agar dapat dengan mudah ditemukan oleh mesin pencari.

3. Periklanan berbasis klik pencarian berbayar (PPC advertising), memungkinkan pemasar membeli halaman hasil pencarian internet berdasarkan kata kunci dan kalimat yang dipilih.

4. Pemasaran afiliasi dan kemitraan strategis (affiliatemarketingandstrategicpartnership).Kegiatan bermitra dengan organisasi/perusahaan lain dan website untukmencapaikeuntungan bersama dari sebuah kerjasama untuk mempromosikan produk atau layanan.

5. Hubungan masyarakat online (Online PR). Menggunakan saluran komunikasi online seperti press release, sindikasi artikel (RSS), dan blog untuk menciptakan persepsi positif atas merek dan/atau untuk menempatkan organisasi/perusahaan sebagai pihak yang berwenang di bidang tertentu.

6. Jejaring social (social network). Sebuah peluang pemasaran, namun saat ini belum ada seseorang pun yang bisa menawarkan sistem periklanan dengan sangat fokus ke kelompok masyarakatyang sedikitatas dasar informasi profil yang didapatkan dari situs jejaring sosial.

7. E-mail pemasaran (e-mailmarketing). Surat elektronik masih menjadi alat yang penting untuk kegiatan pemasaran digital, dikirimkan dengan tujuan untuk menjaga hubungan antara konsumen 
yang sudahada maupuncalon konsumen yang bersedia menerima informasi lewat e-mail.

8. Manajemenhubungankonsumen(CustomerRelationshipManagement).Menjagakonsumenyangsudah ada dan membangun kerjasama yang saling menguntungkan dengan mereka adalah salah satu elemen penting dari kegiatan pemasaran digital.

Untuk pemasaran secara digital yang bisa digunakan oleh UMKM dalam menghadapi era industri 5.0 yaitu pemasaran afiliasi (affiliate marketing), sosial media marketing, dan digital marketing. Penggunaan alat pemasaran online tersebut tergantung dari UMKM yang akan menggunakannya.

\section{METODE}

Adapun tempat penelitian dilakukan melalui studi literatur serta wawancara langsung dengan pemilik Bontot Salminah di Kelurahan Warung Jaud, Kecamatan Kasemen, Kota Serang, Provinsi Banten. Penelitian ini dalam bentuk studi kasus tunggal terpancang. Studi kasus terpancang adalah penelitian dimana penelitian tersebut terarah pada satu karakteristik. Artinya penelitian tersebut hanya dilakukan pada satu sasaran (satu lokasi, atau satu objek). Terpancang artinya peneliti di dalam perencanaan penelitiannya sudah memiliki variabel yang menjadi fokus utamanya, sebelum memasuki lapangan studinya (Kusuma, Jaka Wijaya; Sukandar, Rani Septiani; Hamidah, 2020). Metode Penelitian menggunakan deskriptif kualitatif dengan melakukan pendekatan rasionalistik. Pengumpulan data didapat dari eksplorasi informasi dari berbagai sumber. Data sekunder didapat dari sumber buku teks, jurnal penelitian, artikel media massa, penelusuran literatur secara online, serta data dari instansi terkait. Penggunaan metodologi penelitian kualitatif yang bersifat deskriptif. Dimana data yang dikumpulkan terutama berupa kata-kata dan kalimat, atau gambar yang memiliki arti lebih dari sekedar angka atau frekuensi. Penelitian ini dikategorikan dalam penelitian deskriptif kualitatif penelitian ini dilakukan untuk mendapatkan analisis yang cermat terhadap suatu fenomena sosial tertentu. Penelitian mengembangkan konsep dan penghimpunan fakta, tetapi tidak melakukan pengujian hipotesa. Dalam penelitian ini dipilih jenis penelitian kualitatif yang bersifat deskriptif karena hanya ingin memaparkan situasi dan peristiwa, mendeskripsikan secara rinci dan mendalam mengenai kondisi yang sebenarnya terjadi menurut kondisi nyata dilapangan, dalam hal ini adalah tentang strategi promosi pemasaran online Bontot Salminah dan tidak dicari atau menjelaskan hubungan serta tidak menguji hipotesis atau membuat prediksi. 


\section{HASIL DAN PEMBAHASAN}

\section{Survey Bontot Salminah}

Lokasi Bontot Salminah di Kelurahan Warung Jaud, Kecamatan Kasemen, Kota Serang, Provinsi Banten. Usaha yang dijalankan selama puluhan tahun ini membuat bontot sebanyak 10-15 kg setiap harinya. Sedangkan untuk bulan puasa peningkatan bontot bisa mencapai 5 (lima) kali dari pembuatan bontot secara normal.

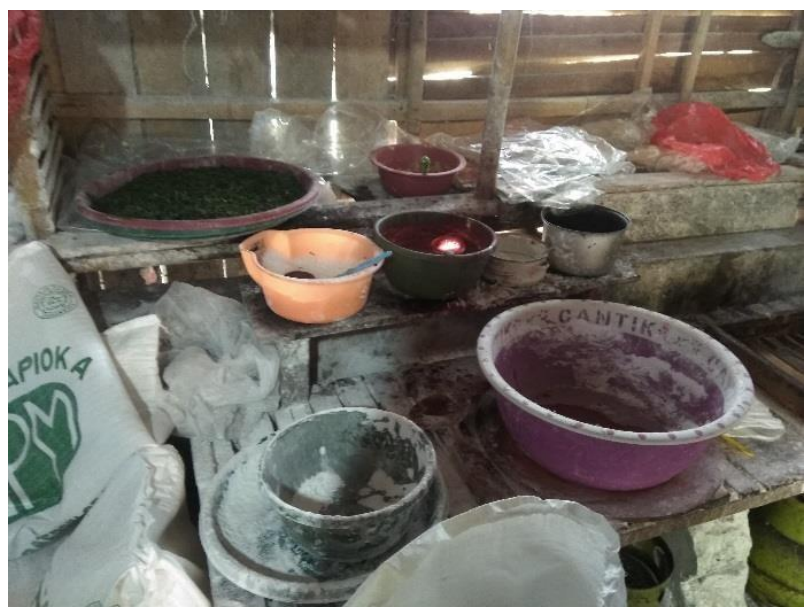

\section{Gambar 2. Bahan-Bahan Pembuatan Bontot Salminah (Sumber: Foto Pribadi)}

Adapun bahan pembuatan Bontot Salminah adalah sagu dan terigu, terasi, bumbu rempah racikan, dan pewarna makanan. Semua bahan tersebut dicampur dan diaduk, lalu dimasukkan ke dalam loyang cetakan. Kemudian dikukus dan diangkat. Setelah dingin lalu dipotong dan siap dipasarkan

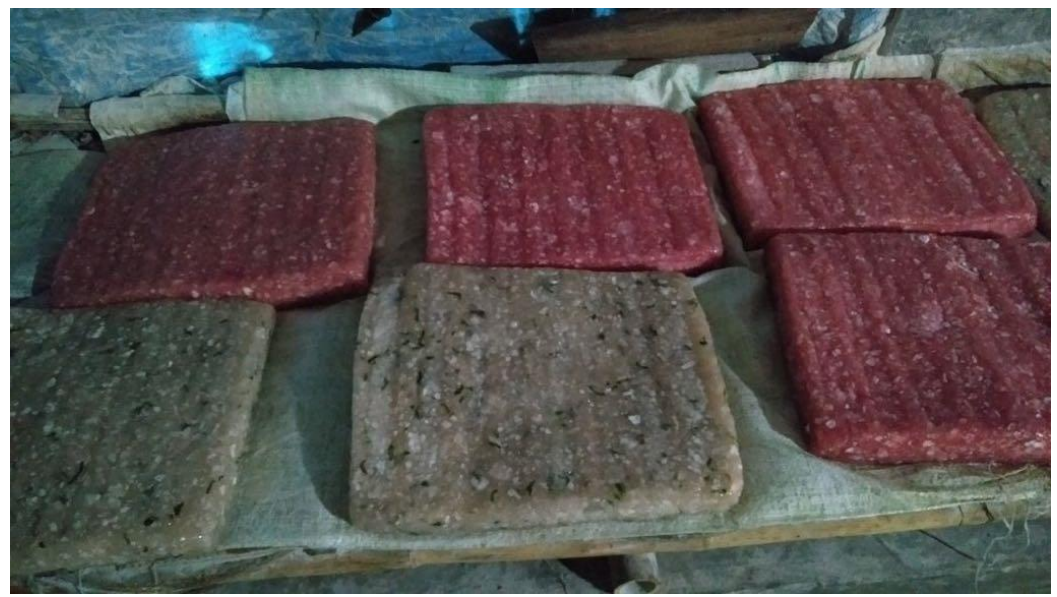

Gambar 3. Hasil Bontot Salminah Diangkat dari Loyang (Sumber: Foto Pribadi) 
Setelah berbincang dengan pemilik dan pekerja Bontot Salminah, usaha tersebut sudah dijalankan puluhan tahun dan selalu memasok kebutuhan bontot setiap hari ke Pasar Rau baik untuk konsumsi sendiri maupun untuk dijual lagi, untuk panganan saat piknik, bahkan untuk oleh-oleh sanak keluarga ke luar kota.

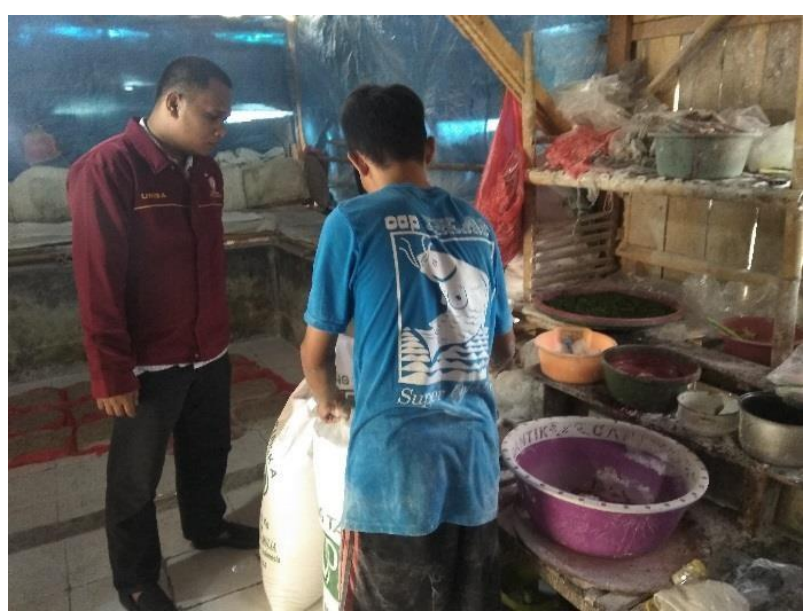

\section{Gambar 4. Berbincang dengan Pekerja Bontot Salminah (Sumber : Foto Pribadi)}

\section{Pengembangan Produk Kemasan, Label, Merek}

Dalam pengembangan produk memerlukan beberapa referensi dari berbagai sumber, baik internet maupun sumber lainnya. Suatu produk akan mempunyai value added bila di dalam produk tersebut tercipta suatu ciri khas yang menggambarkan differensi produk dengan produk yang lain. Sebagai contoh Bontot yang dikemas dibawah ini tapi tidak terdapat nama merek, produsen, jaminan, serta kandungan isi Bontot dan bagaimana cara mengkonsumsinya. 


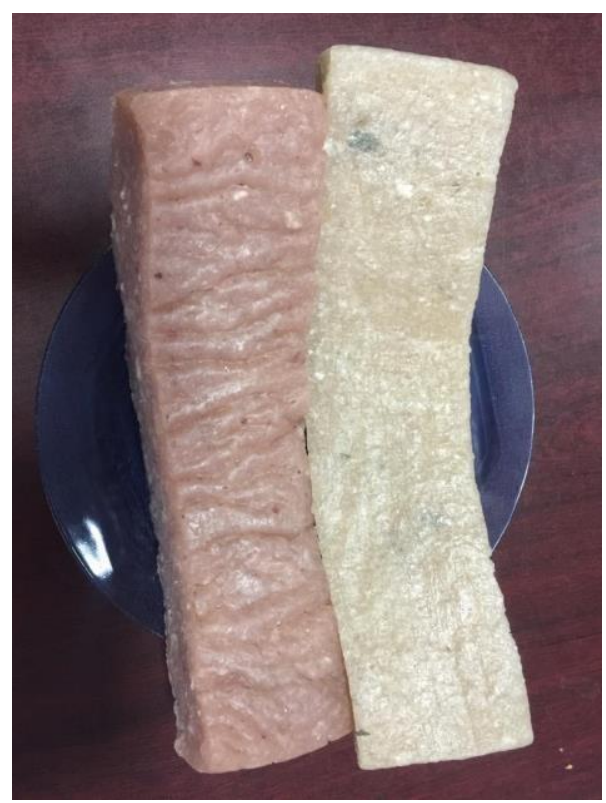

Gambar 5. Bontot sebelum dikemas dan diberi label (Sumber: Foto Pribadi)

Kemudian lihat pula setelah diberi nilai tambah berupa, nama merek dan label, p-IRT sebagai jaminan bahwa Bontot mendapat izin dari dinas terkait serta layak konsumsi. Seperti terlihat pada gambar berikut :

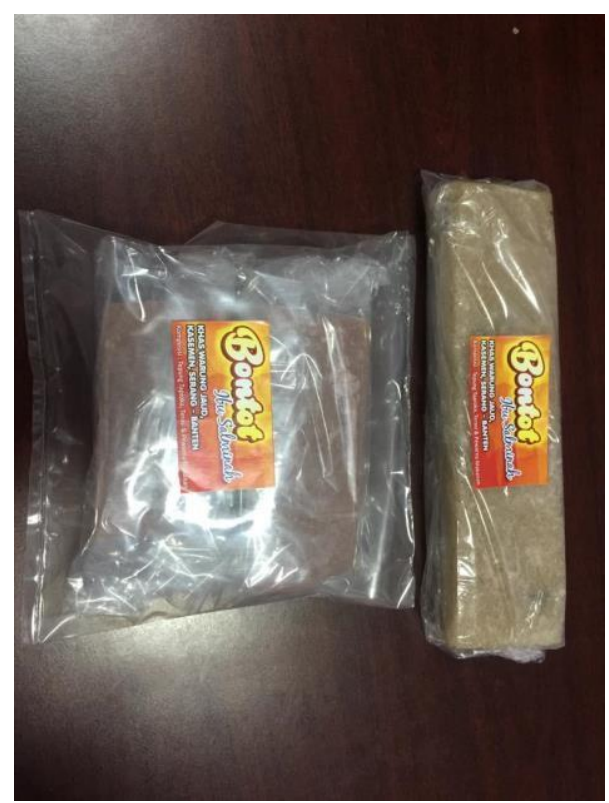

Gambar 6. Bontot Salminah setelah dikemas dan diberi label (Sumber : Foto Pribadi)

3. Pemilihan Pemasaran Online dalam menghadapi Era Indutri 5.0 
Seiring dengan era industri 4.0 yang sudah dilalui dan society 5.0 yang sedang dijalani. Tantangan ke depan menghadapi era industri 5.0 yang sudah ada di depan mata. Era industri 5.0 ini bisa menjadi ancaman khususnya para UMKM lokal yang tidak mau dan tidak bisa beradaptasi dengan era ini. Akan tetapi menjadi peluang dalam membangkitkan UMKM menuju go internasional dikenal seluruh dunia.

Terdapat 3 pilihan pemasaran dalam memasarkan Bontot Salminah ini, yaitu

1. Sosial media atau jejaring sosial marketing, terdapat aplikasi yang sering digunakan oleh para pengguna aplikasi ini oleh orang indonesia yaitu, Facebook dan Instagram, merupakan strategi awal membuka jaringan dan memberikan informasi kepada khalayak umum akan produk Bontot Salminah. Berdasarkan informasi yang didapat sebagaian besar penjual produk kuliner di Kota Serang menjual produknya melalui aplikasi ini. Disamping lebih murah, calon pelanggan lebih banyak.

2. Toko online, terdapat beberapa marketplace yang bisa memfasilitasi produk untuk dipajang atau ditawarkan. Pemasaran melalui toko ini diibaratkan pasar digital bukan hanya kita saja yang berjualan akan tetapi terdapat pesaing yang lain dengan menjual produk kuliner sejenis. Bontot Salminah ini bisa menjadi peluang, dikarenakan produk lokal dan belum semua orang menjualnya. Siapkan tampilan foto dan deskripsi produk yang akan dijual. Tidak lupa cara pembayaran, nomor kontak, serta pemilihan sistem pengirimannya.

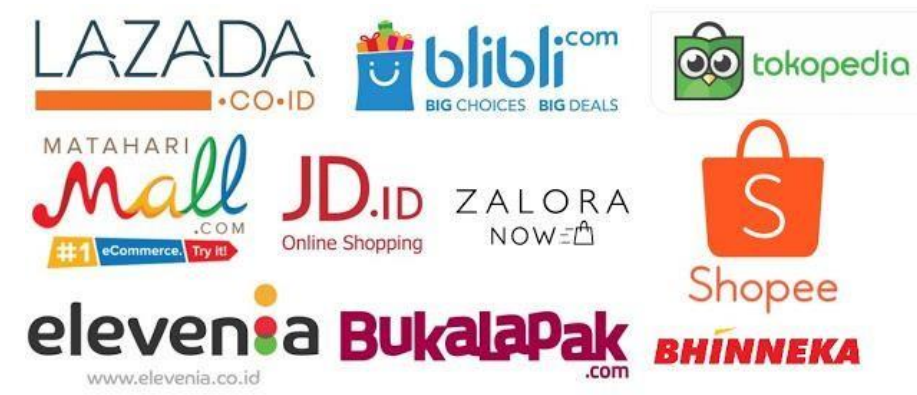

Gambar 7. Marketplace di Indonesia

3. Yang terakhir Digital Marketing, pemasaran ini dibutuhkan keahlian dalam memanage serta menghubungkan dengan berbagai jenis aplikasi lainnya. Dalam hal ini, UMKM Bontot Salminah tidak disarankan untuk digunakan, karena urgensinya tidak terlalu berfungsi untuk diaplikasikan.

Setelah melihat opsi pemasaran online diatas dapat diberikan startegi yang optimal untuk Bontot Salminah dalam menyongsong era industri 5.0, yaitu dengan menggunakan 
Sosial Media Marketing dan Toko Online. Kedua opsi tersebut dirasakan cukup melihat kondisi sekarang mengingat internal Bontot Salminah baik dari segi teknologi, SDM, serta modal menyesuaikan keuangan dari pengelola Bontot Salminah. Terakhir hubungan pelanggan menggunakan telepon atau aplikasi Whatsapp perihal meningkatkan pesanan. Sedangkan pembayaran dan sistem pengiriman diperbaiki ke depannya.

\section{KESIMPULAN}

1. Untuk pengembangan produk Bontot Salminah melakukan label dan kemasan yang menarik (baik dari nama, gambar, ukuran bontot dan desain kemasan) dengan baik.

2. Pemasaran online oleh Bontot Salminah dilakukan melalui Jejaring Sosoal baik Facebook dan Instagram serta masuk ke market place toko online. Karena diyakini sangat efektif mendorong pemasaran. Serta dibuatkan testimoni baik gambar maupun video yang di upload via Youtube.

3. Menjaga hubungan dengan pelanggan serta konsisten terhadap kualitas produk selalu dijaga Bontot Salminah sebagai kritik dan saran agar Bontot Salminah selalu berinovasi lagi ke depannya.

\section{DAFTAR PUSTAKA}

Angipora, Marinus. 2002. Dasar-Dasar Pemasaran. Jakarta: PT. Raja Grafindo Persada. Hal.192.

Cahyorini dan Rusfian. 2011. The Effect of Packaging Design on Impulsive Buying. Journal of Administrative Science \& Organization, 11-21.

Chaffey, D dan PR Smith. 2002. E-Marketing Excellence Planning and Optimizing Your Digital Marketing.

Danger, E.P. 1992. Memilih Warna Kemasan. Jakarta: PT. Pustaka Bina Pressindo. Hal.3.

H.B. Sutopo. 1996. Metodologi Penelitian Kualitatif. Surakarta : Universitas Sebelas Maret Press.

Kotler, Philip. 2000. Manajemen Pemasaran. Jilid 2. Jakarta: Prenhallindo. Hal.478.

Kusuma, Jaka Wijaya; Sukandar, Rani Septiani; Hamidah, H. (2020). Penguatan Pembelajaran Matematika Siap Menghadapi Ujian Dengan Model Pembelajaran Assurance-RelevanceInterest-Assessment-Satisfaction Di Yayasan Nurul Falah Talok Tangerang. Jurnal Abdidas, 1(4), 193-202. https://abdidas.org/index.php/abdidas/article/view/43/33

Nilsson, Johan \& Ostrom, Tobias. 2005. Packaging as a Brand Communication Vehicle. Thesis of Lulea University of Technology. 
Peraturan Pemerintah Republik Indonesia No. 69 Tahun 1999 tentang Label dan Iklan Pangan.

Ryan, D and Calvin Jones. 2009. Digital Marketing: Marketing Strategies for Engaging Digital Generation.

Silayoi, P. and Speece, M. 2005. The Importance of Attributes : A Conjoint Analysis Approach. April 2013, Vol.41.

Swastha, Basu. 1984. Azas-Azas Marketing. Yogyakarta: Liberty. Hal.142.

http://www.wearesocial.com

http://faizatulmuhlisoh.blogspot.com/2016/12/sejarah-makanan-khas-serang-bontot.html diakses pada tanggal 10 April 2020 